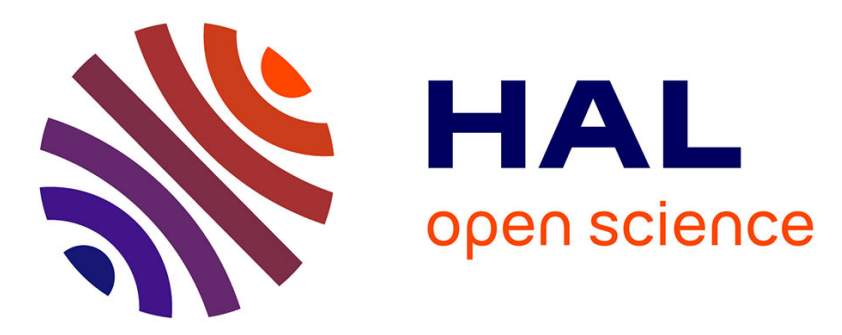

\title{
Impact of a chemical stimulus on two different cell lines through microwave dielectric spectroscopy at the single cell level
}

\author{
Amar Tamra, M.-P. Rols, David Dubuc, Katia Grenier
}

\section{- To cite this version:}

Amar Tamra, M.-P. Rols, David Dubuc, Katia Grenier. Impact of a chemical stimulus on two different cell lines through microwave dielectric spectroscopy at the single cell level. IEEE MTT-S International Microwave Biomedical Conference (IMBioC 2019), May 2019, Nanjing, China. pp.1-4, 10.1109/IMBIOC.2019.8777745 . hal-02401032

\author{
HAL Id: hal-02401032 \\ https://hal.laas.fr/hal-02401032
}

Submitted on 9 Dec 2019

HAL is a multi-disciplinary open access archive for the deposit and dissemination of scientific research documents, whether they are published or not. The documents may come from teaching and research institutions in France or abroad, or from public or private research centers.
L'archive ouverte pluridisciplinaire HAL, est destinée au dépôt et à la diffusion de documents scientifiques de niveau recherche, publiés ou non, émanant des établissements d'enseignement et de recherche français ou étrangers, des laboratoires publics ou privés. 


\title{
Impact of a chemical stimulus on two different cell lines through microwave dielectric spectroscopy at the single cell level
}

\author{
A. Tamra ${ }^{1,2}$, M.-P. Rols ${ }^{2}$, D. Dubuc ${ }^{1}$, K. Grenier ${ }^{1}$ \\ ${ }^{1}$ LAAS-CNRS, Université de Toulouse, CNRS, UPS, Toulouse, France \\ ${ }^{2}$ IPBS-CNRS, Toulouse, France
}

\begin{abstract}
Cellular analysis with microwave dielectric spectroscopy is gaining interest, as it presents attractive characteristics, such as being non-invasive, non-destructive, label-free, while cells may be analyzed directly into their culture medium. Most importantly, the microwave range enables intracellular investigations. This paper confirms such a capability through the evaluation of the different chemo-induced cell responses of two cell lines, HCT 166 and THP1. Moreover, this analyzing method does not only present different capacitive contrasts depending on cell lines. It also allows to extract distinct dielectric variations due to a chemical agent, which are attributed to different cell line-dependent internal modifications of the cells.
\end{abstract}

\section{INTRODUCTION}

Microwave dielectric spectroscopy is under development for decades and is already exploited in various applicative domains such as for water or canalization detection in soils, as well as in agriculture and food for quality assessments [1]. This method presents indeed many attractive features. It is non-destructive, non-invasive, without requiring a direct contact with the material under test and adapted to analyze any type of materials, whether solid, liquid or gaseous. Its high sensitivity to water makes this technique particularly suitable for biological materials sensing due to the high watermolecules content of the living [2]. Moreover, combined to different technologies, the technique gives access to the characterization of matter at many scales, even at the micro and nanoscale with the use of micro or nanotechnologies. This is particularly favorable for the examination of small amounts of liquids, as often the case for cell suspensions and even for single cell analysis [3-9]. Finally, the most important feature of microwave dielectric spectroscopy corresponds to its frequency range. Within the microwave and millimeterwave band, the capacitive bi-lipidic membrane of the cells may be bypassed by the electromagnetic waves, providing access to the constituents of the cells and enabling intracellular investigations. The technique may therefore not only quantify but also discriminate sub-populations of cells [10].

To go even further in demonstrating the capabilities of this sensing method, this paper focuses on evaluating the impact of chemical stimulus on different cell lines. In this case, two human cell lines have been submitted to the same chemical agent at the same concentration and have been investigated while applying microwave dielectric spectroscopy.

To do so, both microwave biosensor dedicated to the analysis of individual cells and associated test setup are briefly described in a first section, while the second section is focused on the microwave characterization of different cells lines submitted or not to the same chemical agent.

\section{Microwave Biosensor for Single Cell Characterization and Test Setup}

A. Description of the microwave biosensor dedicated to the dielectric analysis of single cells

The microwave sensor [3] includes a coplanar waveguide with a capacitive gap at its center, as shown in Fig. 1. The line presents dimensions to exhibit a $50 \quad \Omega$ characteristic impedance with air on top, while realized on a quartz substrate. On top is placed a microfluidic channel, which crosses the waveguide. A mechanical trap is placed just over the capacitive gap in order to trap a cell, where electromagnetic fields are focused.

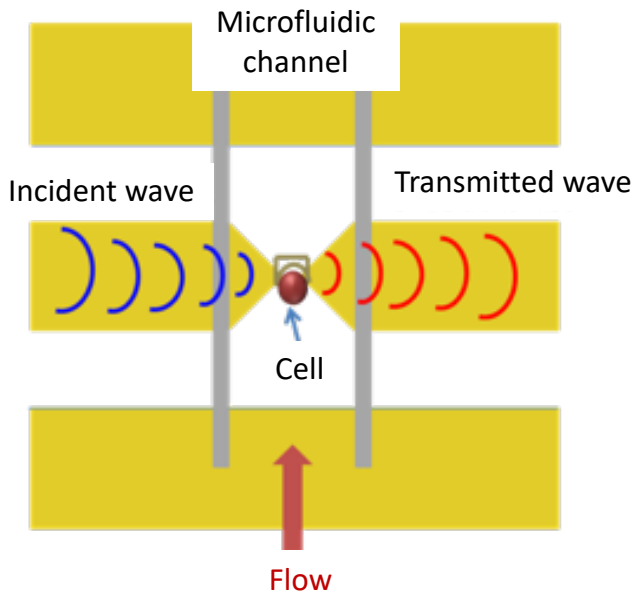

Figure 1. Schematic of the microwave biosensor dedicated to single cell analysis.

Fig. 2 presents a photograph of the sensor, highlighting the sensing area. Even if the microfluidic channel presents a height of $50 \mu \mathrm{m}$, the mechanical trap ensures the cell to be placed just above the capacitive gap to maximize the sensitivity. 


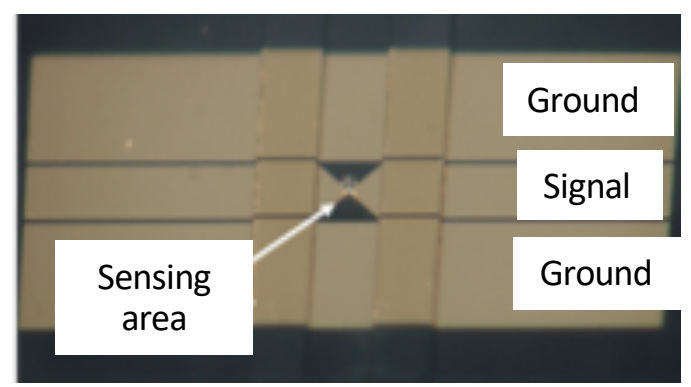

Figure 2. Photography of the microwave biosensor.

\section{B. Cells description and preparation}

For the experiments, two cell lines have been selected, the THP1 and HCT116 cell lines, which correspond to a human leukemic monocytic cell line and a human colon cancer cell line respectively.

HCT116 cells and THP1 cells are cultured in their respective culture mediums: DMEM culture medium ("Dulbecco's Modified Eagle Medium) for the HCT166 cell line and RPMI culture medium (Roswell Park Memorial Institute Medium) for THP1 cells, both supplemented with $10 \%$ of fetal veal serum, penicillin, and streptomycin. Cells are incubated for proliferation at $37^{\circ} \mathrm{C}$ with $5 \% \mathrm{CO}_{2}$.

The chemical treatment used in the study corresponds to saponin, a detergent which creates holes into the cytoplasmic membrane. The obtained permeabilization is irreversible, leading to an artificial death of the cells. A concentration of $0.02 \%(\mathrm{~W} / \mathrm{V})$ during 15 minutes is applied to the cell lines, which are then placed in their respective fresh culture medium before RF measurements.

\section{Microwave test setup and data extraction methodology}

In order to achieve the microwave characterization of the two cell lines, the biosensor is connected to a Vector Network Analyzer (VNA) with coplanar probes and cables. Microwave characterization is performed from $40 \mathrm{MHz}$ to $40 \mathrm{GHz}$. The measurements are realized in two steps.

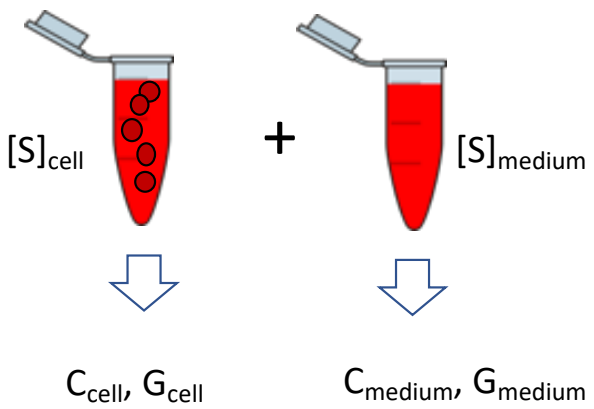

Figure 3. Measurement methodology and extracted electrical parameters.

First the structure is measured, while loaded with the host medium of the cells only, leading to the measurement of the $[\mathrm{S}]_{\text {medium }}$ parameters, whereas, in a second step, the sensor is loaded with an individual cell, leading to $[\mathrm{S}]_{\text {cell. }}$. Using an electrical model of the structure [3], both capacitor and conductance in both configurations, cell with medium and medium only, are extracted and correspond to the two couples of values $\left(\mathrm{C}_{\text {cell }}, \mathrm{G}_{\text {cell }}\right)$ and $\left(\mathrm{C}_{\text {medium }}, \mathrm{G}_{\text {medium }}\right)$ respectively, as depicted in Fig. 3.

Two electrical contrasts, a capacitive one and a conductive one, are then calculated with the following equations respectively:

$$
\begin{aligned}
\Delta C & =C_{\text {cell }}-C_{\text {medium }} \\
\Delta \mathrm{G} & =\mathrm{G}_{\text {cell }}-\mathrm{G}_{\text {medium }}
\end{aligned}
$$

Each medium is considered as the reference of these contrasts. The characterization results are presented in the next section.

\section{MicROWAVE CHARACTERIZATION OF INDIVIDUAL CELLS}

Each cell line has been individually characterized with and without the saponin treatment.

\section{A. Microwave characterization of different cell lines}

First, several individual cells have been measured for each cell lines. Examples of dielectric spectra obtained for 3 individual cells are presented in Fig. 4 and in Fig. 5 for HCT116 and TPH1 cell lines respectively.

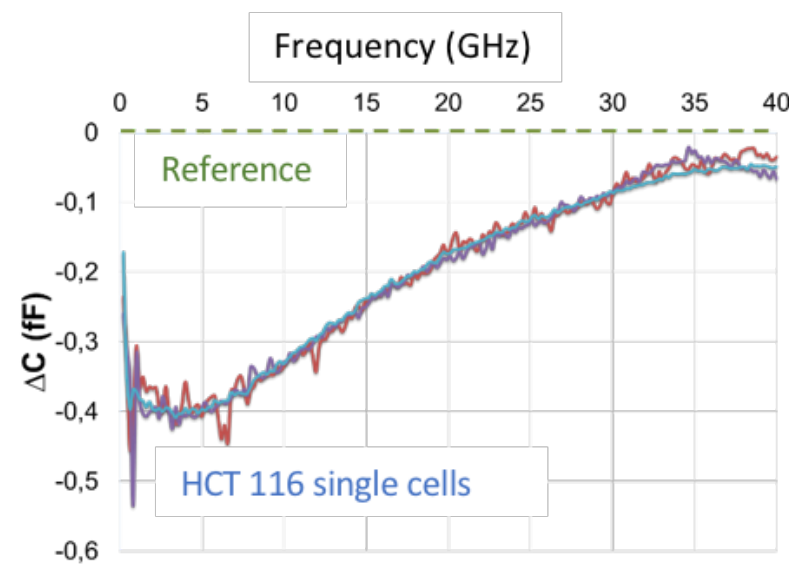

Figure 4. Capacitive contrast spectrum for several individual living HCT116 cells.

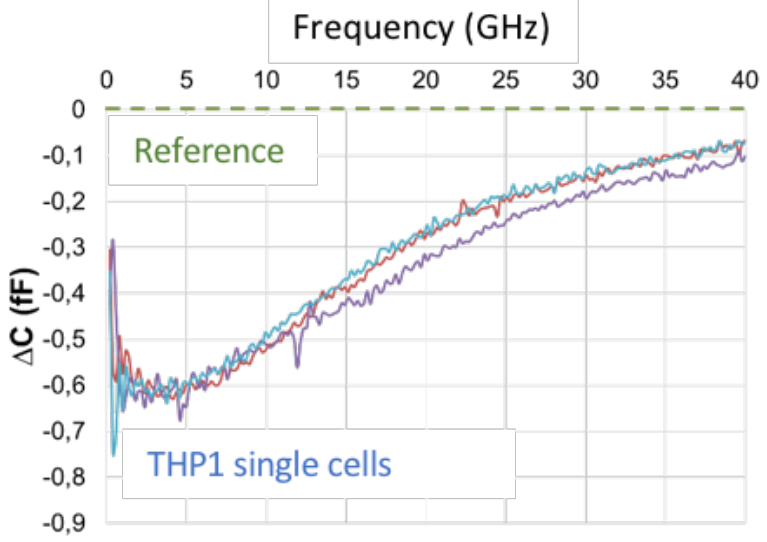

Figure 5. Capacitive contrast spectrum for several individual living HCT116 cells. 
For both cell lines, one may observe that the capacitive contrast is maximal at $5 \mathrm{GHz}$, whereas the absolute value decreases toward the reference zero value while the frequency increases. If cells from the same line are considered, for both lines, the different measured individual cells present quite close capacitive contrasts curves, which differ due to intrinsic variations of the living. They exhibit a maximal average value (in absolute) of $-0.4 \mathrm{fF}$ for the HCT116 cells and - $0.6 \mathrm{fF}$ for THP1 ones at $5 \mathrm{GHz}$. Corresponding capacitive variations are also given in Table I for both cell lines. One may notice that the maximal values are quite distinctive, which confirms the possibility of the microwave dielectric spectroscopy to discriminate cell lines. The zero line on the abscissa corresponds to the reference level of the contrasts, i.e. the culture media.

Based on these first results, we wondered if the sensing technique could be able to distinguish different cell behaviors when submitted to the same chemical stimulus.

\section{B. Dielectric impact of a chemical stimulus on two different cell lines}

Fig. 6 and Fig. 7 present respectively the mean values of the capacitive contrasts of HCT116 and THP1 cells, which have been treated or not with saponin.

Whatever the cell line, the saponin treatment leads to a decrease in the capacitive contrasts in absolute value. The corresponding values are summarized in the Table I. This reduction may be explained by the fact that, due to the permeabilization of the cytoplasmic membrane, an exchange between the intracellular and the extracellular media occurs until reaching an equilibrium between both compartments. Treated cells tend then to present capacitive contrasts, which values move toward the culture medium one, the reference of the measurement. This contrast may not reach zero, as the saponin treatment still keeps the architecture of the cells with organelles inside the cytoplasmic membrane.

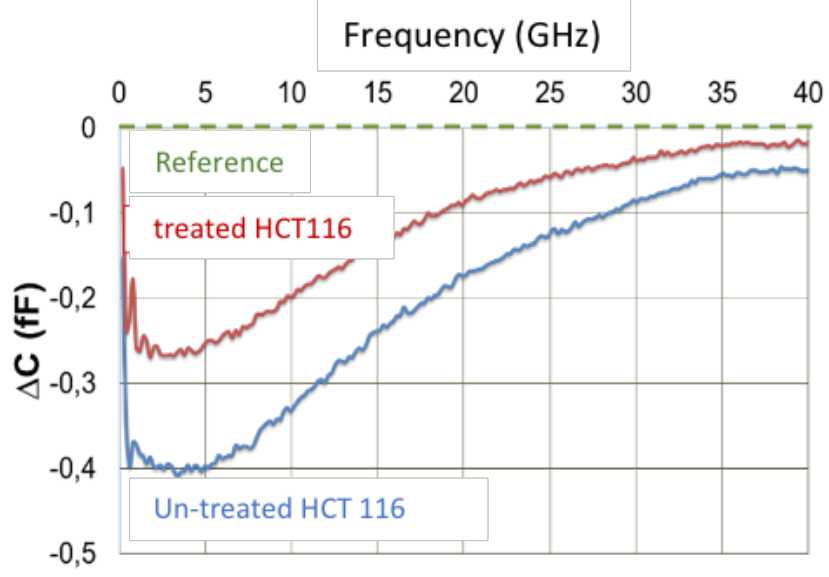

Figure 6. Capacitive contrast spectrum for HCT116 cells with and without saponin treatment.

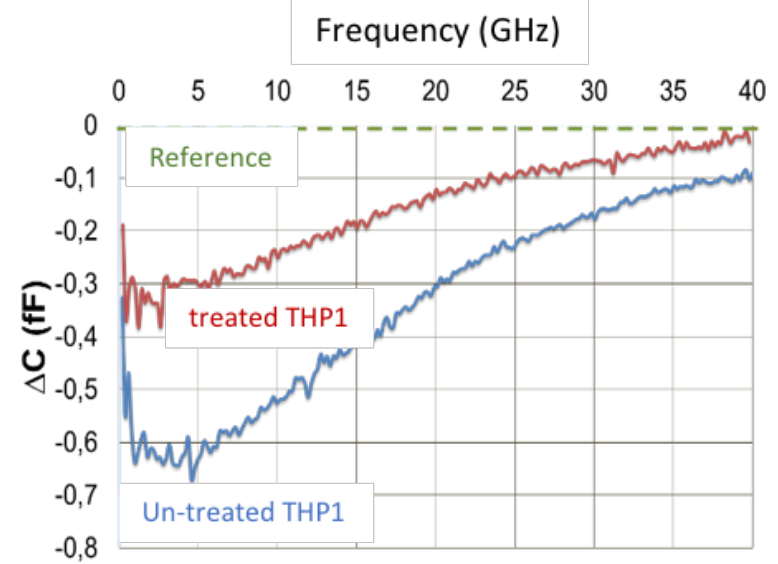

Figure 7. Capacitive contrast spectrum for THP1 cells with and without saponin treatment.

TABLE I

SUMMARY OF THE CAPACITIVE CONTRASTS OF THE CELLS, DEPENDING ON THEIR TYPE, WITH AND WITHOUT A CHEMICAL TREATMENT

\begin{tabular}{|l|c|}
\hline Cell type & $\begin{array}{c}\Delta \mathbf{C} @ \mathbf{5} \text { GHz } \\
\text { (fF) }\end{array}$ \\
\hline Untreated HCT116 & $-0.40 \pm 0.046$ \\
\hline Treated HCT116 & $-0.25 \pm 0.04$ \\
\hline Untreated THP1 & $-0.60 \pm 0.10$ \\
\hline Treated THP1 & $-0.30 \pm 0.077$ \\
\hline
\end{tabular}

As far as the variation of the capacitive contrast is concerned, this one is closed to $37 \%$ for the HCT 116 cell line, whereas the TPH1 cells exhibit a contrast modification of $50 \%$. The $13 \%$ difference between these cells' behaviors may not be only explained by the dielectric variation between both culture media. Internal modifications induced by the chemical treatment must also differ depending on the cell lines, leading to such a measured variance in the cellular chemo-induced response.

\section{CONCLUSIONS}

To conclude, this paper presents the dielectric characterization of two different cell lines, which have been dielectrically compared when submitted or not to the same chemical treatment.

First, cell lines intrinsically present different dielectric properties when characterized in the microwave range. This result well highlights the interest of the intracellular investigation of the microwave dielectric spectroscopy.

Secondly, as the applied chemical treatment is based on the use of a detergent, saponin, which creates pores in the cytoplasmic membrane, while keeping the integrity of the cell, it leads to an artificial death of cells, which may be distinguished with the microwave dielectric spectroscopy technique. 
Thus, this analyzing method does not only present different capacitive contrasts depending on cell lines. It also allows extraction of, due to a chemical agent, distinct dielectric variations, which are attributed to different cell line-dependent internal modifications of the cells. This last result is interesting as it may find applications in the evaluation of therapeutic agents' efficiency notably for personalized treatment.

\section{ACKNOWLEDGMENT}

This work was partly supported by the Université Fédérale Toulouse Midi-Pyrénées, the French region Midi-Pyrénées and the French RENATECH network.

\section{REFERENCES}

[1] K. Kupfer, "Electromagnetic aquametry," Springer, 2010.

[2] A. Vander Vorst, A. Rosen, Y. Kotsuka, "RF/Microwave interaction with biological tissues," Wiley Series in Microwave and Optical Engineering, 2006

[3] T. Chen, F. Artis, D. Dubuc, J. J. Fournié, M. Poupot, and K. Grenier, "Microwave biosensor dedicated to the dielectric spectroscopy of a single alive biological cell in its culture medium," in 2013 IEEE MTT-S International Microwave Symposium Digest (MTT), Jun 2013, pp. 1-4.
[4] Y. Ning, C. Multari, X. Luo, C. Palego, X. Cheng, J. Hwang, A. Denzi, C. Merla, F. Apollonio, M. Liberti, Broadband electrical detection of individual biological cells, IEEE T-MTT, Vol. 62, n 9, pp. 1905-1911, 2014.

[5] N. Meyne, G. Fuge, H.K. Trieu, A-P. Zeng, A.F. Jacob., Miniaturized Transmission-Line Sensor for Broadband Dielectric Characterization of Biological Liquids and Cell Suspensions. IEEE Trans. on Microwave Theory and Techniques, Vol. 63, n ${ }^{\circ}$, 2015, pp. 3026-3033.

[6] Y. Yang, Z. Hanqiao, Z. Junjie, W, Gaoyan, T. Tzuen-Rong, X. Xiangchun, H. Kama, and W. Pingshan "Distinguishing the viability of a single yeast cell with an ultra-sensitive radio frequency sensor," Lab.on a Chip, 2010, pp. 553-555.

[7] A. Tamra, M.-P. Rols, D. Dubuc, K. Grenier. "Microwave Monitoring of Single Cell Monocytes Subjected to Electroporation," IEEE T-MTT, 2017, DOI: 10.1109/TMTT.2017.2653776.

[8] K. Grenier, A. Tamra, A. Zedek, G. Poiroux, F. Artis, T. Chen, W. Chen, M. Poupot, J-J. Fournié, D. Dubuc,. "Low Volume and Label-Free Molecules Characterization and Cell Monitoring with Microwave Dielectric Spectroscopy," IEEE IMBioC, 2018.

[9] K. Grenier, D. Dubuc, T. Chen, F. Artis, T. Chrétiennot, M. Poupot, J-J. Fournié, "Recent Advances in Microwave-based Dielectric Spectroscopy at the Cellular Level for Cancer Investigations," IEEE TMTT, Vol. 61, Issue 5, Part 2, 2013, pp. 2023-2030.

[10] F. Artis, D. Dubuc, M. Poupot, JJ. Fournié, K. Grenier, "Label free discrimination of human lymphoma cell sub-populations with microwave dielectric spectroscopy," IEEE International Microwave Symposium Digest 2018, Philadelphia, USA, 10-15 June 2018 